TURIZAM

Volume 24, Issue 3

$137-148(2020)$

ORIGINAL

SCIENTIFIC PAPER

\title{
To Seek One's Fortune: Labour Migrants from the Western Balkans in Norwegian Hospitality Industry
}

\author{
Bojana Kalenjuk ${ }^{A}$, Bojan Đerčan ${ }^{A}$, Dragan Tešanović ${ }^{A}$, Tamara Lukić ${ }^{A}$, Maja Banjac $^{A}$ \\ Received: May 2020 | Accepted: July 2020 \\ DOI: 10.5937/turizam24-26429
}

\begin{abstract}
The hospitality industry is known for the large fluctuation of labour. The subject of this study is hospitality workers from the countries of the Western Balkans who are currently employed in the catering business (cooks, chefs) in a Scandinavian country - Norway. The task was to investigate the reasons for their coming to the northern regions, as well as the experience and knowledge gained while working in their restaurant facilities. The aim of the paper was to obtain information on the reasons for the selection of these sites, differences in work and experiences, as well as future plans. The results showed that there is a considerable satisfaction with the work in the Scandinavian countries. The key item in easy adjustment and destination selection is played by living standards i.e. income, which is the focus of the interest of migrant workers from the Western Balkan countries.
\end{abstract}

Keywords: Labour migration, restaurant, hospitality, chef, Western Balkans, Scandinavian countries

\section{Introduction}

Every day, an increasing number of qualified hospitality workers are looking for better working conditions that will enable them better-living conditions (Choi et al., 20oo). This has affected large population migrations (Janta et al., 2011; Joppe, 2012) from South-eastern Europe, primarily to Germany and other EU countries, followed by Norway and Canada (Commissariat for Refugees and Migration of the Republic of Serbia, 2016). In this case, hospitality workers can be considered as "working tourists" and as "migrant tourism workers" (Underthun, Jordhus-Lier, 2017). Allen and Mac Con Iomaire (2016) discuss the migration of hospitality workers, chefs and cooks, trying to find out why they are more numerous in restaurants than in hotels, which is not the norm everywhere (Kalenjuk et al., 2020).

A Department of Geography, Tourism and Hotel Management, Faculty of Sciences, University of Novi Sad, Corresponding author: bojana.kalenjuk@dgt.uns.ac.rs 
The tourism in certain countries successfully survives thanks to the seasonal labour (Tuulentie, Heimtun, 2014). These are international workers who, in many tourist centres, are invaluable according to Devine et al. (2007). And, what is most important, it can support depopulation in some areas (Möller et al., 2014). Carson, Carson and Eimermann (2017) state that most research focuses on migration to the warmer regions of the world, with a small focus on cold destinations characterised by winter sports, such as Scandinavian countries.

Hospitality is specific for its large turnover of employees, which significantly affects the quality of work of all sectors (Wildes, 2008; Bufquin et al., 2016). According to Heimtun (2012) Scandinavia, in recent years, represents a focus of interest for seasonal hospitality workers whose main focus are earnings, but motives can be related to hygiene needs, and development needs (Lundberg et al., 2009). The satisfaction of workers primarily affects their retention or further search for better working and living conditions that will also provide for their family (Wildes, Parks 2005; McCabe et al., 2005; Kalenjuk et al., 2020).

In some areas, seasonal workers are very important for the success of hospitality and tourism (Alverén et al., 2012), and their return to that destination or workplace depend on the working conditions. Susskind et al. (2007) state that the work experience and attitudes of employees closely related to the customer's satisfaction, and that the support by the work collective has a great influence, even greater than the support of the management itself.

The level of education of the hospitality staff influences the choice of the destination that will enable them to earn a good income (Thulemark et al., 2014). The facilities for the education of hospitality staff are often conditioned by the needs of the market (Zopiatis et al., 2014), which is conditioned by the population size.

The subject of this research is the work of hospitality workers (cooks) from the territory of the Western Balkans, more precisely from the former republics of Yugoslavia (today's Republic of Serbia, Bosnia and Herzegovina, Macedonia and Montenegro) in the hospitality facilities in Norway. The aim of the paper is to get information about the differences in work and future plans. The task of the paper is to answer the following research questions:

- Who are the workers coming to work in Norwegian restaurants (what is their structure)?

- What are their reasons for selecting Norway?

- What are their experiences?

- How satisfied are they with working and living conditions?

- What are their future plans?

\section{Conceptual Framework}

\section{Migration of hospitality workers}

Hospitality is a labour-intensive activity (Choi et al., 200o) and a key economic sector (Zampoukos, Ioannides 2011) which is characterised by labour migration (Anderson 2010). Previous research prove that in some cases the aim of migration is gaining work experience and learning a language (Janta et al., 2011), however, the reasons and initial motivations may be different (Lundberg et al., 2009). Many authors dealt with issues related to the sustainability of the migration itself (Lundmark, 2006), and motives. Paniagua (2002) states that the main reason for moving from urban to rural areas is employment, but that there are other motives too. Chan and Wang (2015) reveal seven motivation of seasonal workers in northern countries in 
their research: professional development, search for newness, decent wages, friendships with colleagues, a favourable working environment, a view of nature and spending time in it, and community integration. Alverén et al. (2012) state that only the satisfaction with work influences their return to a hospitality facility or destination.

According to The International Labour Organization (ILO), the number of international migrants in 2013 was 232 million, of which the number of labour migrants amounted to 115 million. Joppe (2012) states that, among international migrants, the biggest share take the hospitality and tourism workers, whose number grows every day. Thulemark et al. (2014) state that certain destinations become suitable for attracting highly qualified and well-paid people, which depends on a number of factors within the country itself (Kostadinov Koroutchev, Iashvili, 2015). Zampoukos and Ioannides (2011) in their research cite London, Stockholm, and Amsterdam as the targeted destinations of hospitality workers.

In certain areas characterised by a small number of inhabitants, migration of hospitality workers can affect the increase in the population number by their permanent settling in these areas (Möller et al., 2014). Iversen and Jacobsen (2015) state that this primarily relates to poorly populated rural areas. It is important to highlight the benefits that the destination has from the migrant workforce. Accordingly, Bosworth and Farrell (2011) state that, in addition to fighting for themselves through work, the migrant workers often stimulate other local firms influencing local trade by increasing competition and raising the standard. Issues related to the working and living conditions of migrants who came from Eastern Europe to Norway were addressed by Rye and Andrezejwska (2010), noting that migrants often agree to work for incomes that are below the standard living wages in Scandinavian countries because they are still higher than those they would have in their own country.

Studies have shown that even those destinations that are underdeveloped are often attractive to working migrants if the living conditions are favourable and allow the nature lovers (who are fleeing from urban areas) to have decent living conditions (Carson et al., 2017). Carson et al. (2017) emphasize that the retention of this group of migrants in the northern winter regions cannot be long and is most often related to the possibility of practising winter sports. This is confirmed by research that identified winter sports as important segments in attracting seasonal workers, as a secondary motive for attracting workers (Lundmark, 2006; Tuulentie, Heimtun, 2014).

Carson and Carson (2017) state that immigrants in the Scandinavian countries have emerged as an important driver of new tourism products, processes, markets, and the introduction of a range of new ideas, skills and external links to the region. They emphasize that, sometimes, immigrants also affect the limited contribution of networking, cooperation and knowledge exchange with local stakeholders in tourism, which also has negative sides. As a reason, they list the lack of interaction, including the socio-cultural distance between immigrants and local residents, limited levels of trust and reciprocity, differences in development priorities, lifestyle, and connections between immigrants. The greatest significance of immigration is seen in the sparsely populated rural areas.

According to the data from the population census in the diaspora in 2010, over 2500 Serbs settled in Norway (Bubalo-Živković et al., 2017). In 2014 alone, 563 migrants from Serbia to Norway were registered (Commissariat for Refugees and Migration of the Republic of Serbia 2016). According to the 2016 census, from the territory of Western Balkans, the highest number of immigrants come from Bosnia and Herzegovina (8 207) and Kosovo and Metohija ( 5666$)$, in both cases with a slightly larger share of the male population (https://www.ssb.no/ en/innvregsys/). 
In the last few years, not enough attention was paid to research investigating kitchen workers (Allen, Mac Con Iomaire 2016). Wellton, Jonsson and Svingstedt (2017) state that there is very little scientific research about everyday work in restaurants that are focused on the way the kitchen works. Mac Con Iomaire (2016) in his research, among other things, identifies the shortage of cooks as a problem, finding out through an interview with top Swedish chefs that it is very difficult to find a person who is willing to work 80 to 90 hours a week, which reflects on the satisfaction with the work and organizational commitment of hospitality workers (Bufquin et al., 2017). Working in the kitchen is a rather complex process (Magnusson Sporre et al., 2015). Allen and Mac Con Iomare (2017) state that the factors that are necessary for the success in the culinary industry include professionalism, individual characteristics, leadership skills, managerial skills, and job interaction.

\section{Methodology}

A semi-structured interview was used for the research as the most reliable form for obtaining this type of data. The empirical basis of this research consisted of interviewing 16 cooks - chefs from Serbia (7), Bosnia and Herzegovina (5), Macedonia (2) and Montenegro (2), who have been working in Norway for more than 2 years.

Interviews were conducted during the Christmas and New Year holidays (between 25.12.2017. and 20.01.2018.), when the employees from the Scandinavian countries came home and had free time to share information about experiences and insights. Respondents from Republic of Serbia and Bosnia and Herzegovina were interviewed face to face. The rest of the interviews were conducted via Skype. Interviews took between 55 and 75 minutes. Half of the interviews were recorded and then transcribed for the purposes of this paper. The interviewees are listed in the alphabetical order.

According to the instructions of scientific methodology for obtaining qualitative data (Brotherton, 2015), the structure of interview questions was originally tested on one respondent from the Republic of Serbia, after which it was supplemented and used for further data acquisition. The questions were grouped according to the research questions set out in the task of the paper:

1. The first part dealt with questions about the socio-demographic characteristics of the respondents, such as gender, age, relationship status, professional qualification and work experience.

2. The second part of the research was about getting answers to the questions about the reasons for choosing Norway: Why did you opt for the Scandinavian countries? What was the decisive factor? What information did you have?

3. The third part of the research related to the work experience: To what extent does the work differ from the one you are used to or learned in your country of origin? What particularly excited you in their system of work? What do you dislike about their system of work? How much does the demand for food differ from the demand in your country?

4. The fourth part of the research was tasked with finding information about the satisfaction of migrants through the following questions: What is your overall satisfaction with work and life? Which was most often continued with: What excites you most? To what extent is it different from work and life in your county? 
5. The last part of the research was related to their future plans in life and work or intentions about staying in the Norwegian tourist centres: What are your future plans? Why? What will be the deciding factor?

\section{Results and discussion}

The interpretation and discussion of the obtained data was carried out based on the information collected during the interviews. The answers, grouped according to the questions, are shown later in this paper. Certain response groups are fully indicated, while responses of a similar structure are grouped and discussed.

\section{Analysis of the structure of the respondents}

On the basis of the sampled sample (available), the majority of respondents were male (14) which coincides with the research findings that hospitality (especially the kitchens) are dominated by men (Neuman et al., 2016; Neuman, 2017). In catering circles for interviewing it was very difficult to find female members who currently work in Norway from the territory of Western Balkans. The largest number of respondents (12) were aged between 30 and 40, which coincides with the finds of Allen and Mac Con Iomare (2016), which say that the largest number of workers in kitchens is from that age group. The remained consisted of one respondent under the age of 30 and three subjects older than 40. All respondents were from larger cities of the Western Balkans. Most respondents (12) are in relationships or marriages with partners who do not reside with them in Norway and the majority (11) do not have children yet.

Among the respondents, most are employed as cooks, and only two are holding the position of sous chef (with a stay longer than 5 years in Norway). Based on the interviews it became clear that their current earning were higher than 2 ooo euros, which is considered a lower income in Norway, which has a positive connotation for the respondents since, for the same engagement, in Republic of Serbia they would have a salary of around 300 euros (which is lower than the average of 402 euros net) (http://www.neobilten.com/prosecne-zarade-po-zaposlenom-u-republici-srbiji/), where the statutory minimum wage is around 230 euros. Average incomes are similar to incomes of other Ex-Yu countries. Some studies state that the salaries in the Norwegian hospitality industry are not large, compared to other industries (Skalpe, 2003), but migrants agree to work for salaries that are lower than average (Rye, Andrzejewska, 2010).

All the respondents had over 10 years of experience in the industry and more than 2 years working as cooks. Only one respondent had more than 10 years of work experience in Norway. Among the respondents, there were no persons working in other positions. Most respondents (9) are employed in hotel restaurants, four work in a la carte restaurants that offer international dishes, two work in a la carte restaurants that offer Scandinavian dishes and one in a mass catering restaurant (workers canteen). Most hospitality facilities are located in rural tourist areas, as explained by Iversen and Jacobsen (2015) in their research as they are most suitable for attracting migrants. The respondents work in northern parts of Norway in the villages: Honningsvåg, Sandnessjøen, Sogndal, Laerdal, Mosjøen, and Mo i Rana. Eleven respondents go to Norway every year for work during the summer season, while the rest work and reside in Norway throughout the year.

All respondents have completed high school for cooks, three of them competed a higher school for hospitality (whose diploma they did not enclose when applying for a job). Two 
respondents are in the final stages of gastronomy studies in Serbia but are unwilling to complete them anytime soon. It is interesting to note that the respondents, as a reason for not disclosing their University degrees in application, state it is easier to find a job without them. This can be seen in the explanation of the Respondent E (Serbia, 38): "I never applied for a job with my diploma because I was advised so by my older colleagues. Scandinavians, like everyone else, are looking for cheap labour, and with a higher education degree, they would have to pay me more than 2 ooo euros, which is just the reason to refuse me. The salary at the level of high school is enough for me. Everyone would love to make more money. In our case, something is better than nothing."

Contrary to the statements of respondents who came to Norway in the past 5 years, Respondent $\mathbf{O}$ (Montenegro, 52) states the following: "I came to Norway almost two decades ago because my brother was here. At that time the highly skilled workforce was really sought after and the higher education hospitality diploma opened doors to employment for me. Today it works a little differently."

\section{Analysis of the reason for selecting Norway}

The reasons for selecting the Scandinavian countries are not specific. They are largely related to existential needs or finding a place with decent living conditions and solid income (all respondents). The main prerequisite is the adaptation to climatic characteristics and, as stated by Carson et al. (2017), it may be the love for winter sports, although it was not found in the respondents who participated in the research.

The proof of this claim was given by Respondent C (Bosnia and Herzegovina, 38) who stated: "In the post-war period I did not have many options for going away for work, it was important for me to leave as soon as possible, and the north was always interesting to me. I did not have any issues with the climatic conditions so I quickly packed and left without much hesitation. I am here to this day and I did not regret."

\section{Analysis of work experience in Norwegian hospitality facilities}

Initially, a brief question was posed to all respondents: How would you evaluate your skills and knowledge in the hospitality industry before arriving in Norway? Most respondents (9) gave a median score (3), and the rest (7) a score of 4 (on a scale from 1 - very poor to 5 - excellent). Respondents explain the scores by giving answers to the following question: To what extent does the work differ from the one you are used to or learned in your country of origin?

The respondents state that the differences are enormous adding segments that relate to the culture of the people and the treatment by employers which is of great importance to them.

This statement is supported by the following selected answers:

Respondent A (Serbia, 32): "Everything is very different. The nation is very literate and cultured, the job is appreciated and paid."

Respondent F (Bosnia and Herzegovina, 29): "To a large extent and the difference in mentality plays an important role."

Respondent G (Montenegro, 33): "The organisation is simplified wherever possible, and the rules are respected to the smallest detail. And there is a constant effort to improve the work. So it is easier to work in such an environment."

Respondent B (Macedonia, 31): "I was not fully prepared for work in Norway because they have the more modern technology of all kinds, from devices and apparatus to telecommunications. 
Many things needed to be learnt from the beginning or built on the already acquired knowledge. Modern equipment in the kitchen means a lot, and this is seen in the quality of the final products."

Respondent J (Serbia, 33) states the following: "I finished a four-year high school for cooks and, specifically at the very beginning of working in Norway, my experience in the profession from Serbia meant a lot to me. When arrived the first time I had some 6 years of experience of working in various restaurants. Of course, there were many things that I did not have the opportunity to see and learn at home, such as working on more modern equipment and a lot of foods that are used sparsely or not at all in my country."

In addition, the importance of applying modern equipment was noticed in the answers of the respondents. As stated by Flaster and Lyon (2017), it allows the kitchen staff to create unusual dishes and achieve excellent levels of consistency and precision. However, as an important segment, the respondents state the organisation of work (Fine, 1990).

In order to obtain information on the positive and negative aspects of the work, the respondents were asked the question: What particularly excited you in their system of work? This question was aimed at getting information about their impressions.

Respondent B (Serbia, 38) states, in addition to the good organisation of work, the following: "A lot offoodstuffs has already been processed and packaged, and they are ordered like this." This segment about foodstuff is even frowned upon in the work itself when the quality of foodstuff is in question. The structure of responses from others is similar. In this sense, selected answers of the following respondents are stated:

Respondent L (Serbia, 31) adds: "Respecting working hours, paid overtime, equality of all workers, regardless of gender or level of education."

To that, Respondent E (Serbia, 34) adds: "I like how they take into account food costs and food waste. That is what in Serbia is still not implemented."

With the attempt to get to the possible bad sides, the following question was raised: What do you dislike in their system of work? The Respondent A (Serbia, 32) responded briefly: "I like everything!", and the other responders had a similar answer.

Respondent J (Serbia, 33) stays the following: "In my work I dislike the large usage of industrial products, a lot of ready-made or semi-finished products that require minimal finishing touches... on one hand it makes the work easier, but on the other hand it loses the authenticity that a cook can give to that dish."

Similarly, the Responded D (Bosnia and Herzegovina, 39) states: "What I did not like is that in some cases the advantage of fresh food is ignored. Conserved food, powdered sauces, and similar things are often used to a great extent. It often makes the work easier but for us, who are accustomed to preparing dishes from fresh ingredients, there is always the feeling that, for example, a simplest potato puree would be tastier and nutritionally more useful if prepared from fresh potatoes and not from canned ones."

An interesting detail is given by Respondent I (Bosnia and Herzegovina, 32): "An amazing number of customers is allergic to certain ingredients. That is very difficult to follow because of the amount of semi-finished products used, whose composition is difficult to control."

The interview wanted to obtain data on food consumption and that is why the following question was asked: How much does the demand for food differ from the demand in your country?

Respondent I (Bosnia and Herzegovina, 32) states: "The inhabitants and the tourists are eating out in hospitality facilities much more often." This is explained by Respondent K (Ser- 
bia, 34) in the following way: "The daily meal pattern is different to ours, it is known when the meal time is and this is always respected by the guests."

Respondent P (Serbia, 46): "I spent one season in a la carte restaurant and I must admit that the difference in demand compared to the one in our country noticeable. The guests were locals and I can say that they visit the restaurants more often and the food is ordered in large quantities." In favour of this claim Hansen et al. (2005) lists five main elements for satisfying a la carte restaurant guests, where food is in the first place, and the interior, the possibility of socializing, company and the atmosphere of the restaurant are second. Most of the respondents agree with this statement and with the mentioned respondents' statements, which explains the demand for catering workers and the growing reason for choosing this work environment.

\section{Analysis of work and life satisfaction}

In order to obtain data on the overall satisfaction of migrants, the following question was asked, with certain follow-up questions: What is your overall satisfaction with work and life? During the interview, half of the respondents assessed the living and working conditions with the highest grade ( 5 - excellent) and the other half with grade 4 (very good), which gives a high average grade at the level of this study. Hospitality workers often return with negative experiences but also go with a variety of motives (Lundberg et al., 2009) compared to these relating to finding better living and working conditions (Janta et al., 2011). With high scores the respondents stated the following:

Respondent H (Serbia, 39) shortly says: "There is no stress." Respondent N (Macedonia, 39): "I work normally, the salary is regular, you can travel, and you can save and start a family." Respondent J (Serbia, 33): "In addition to the work that does not take me more time than it should, and the lack of stress in regard to everyday existence, relationships with colleagues, I have a lot of free time that I can spend in peace with the desire for further development and creative expression." In favour of successful tourism development, it is important to emphasize that work satisfaction significantly reflects on the satisfaction of guests (Susskind et al., 2007).

Respondent M (Bosnia and Herzegovina, 45): "The worker is protected because the employers adhere to the labour law. I can also say that I like the way in which employers react to the demonstrated initiative - they are ready to give responsibility and to adequately reward it. Our worker is appreciated and supported there." This can be added on to the research carried out on this subject and it confirms that support from your superiors positively influences the organisational commitment and employee satisfaction (Kang et al., 2015).

Respondent G (Montenegro, 33): "Pure income, I do not have costs as I live in the hotel where I work. And what more do I need?" Based on the above, we see the elements that were studied by Underthun and Jordhus-Lier (2017), confirming that by working in hotel kitchens the hotel becomes a place of work and life.

\section{Analysis of future life and work plans}

In order to obtain information on future life and work plans, dealt with by Wildes and Parks (2005) and McCabe et al. (2005), that is, staying in the locations, it became apparent that all the respondents had a plan to find a job that would allow them to bring over their marital partners and to permanently settle or earn a certain capital for the family in the home country, which can best be seen from the answer of Respondent F (Bosnia and Herzegovina, 29): "My plan is to find an employer who will be satisfied with my work and to bring my wife. With joint work, 
we would relatively quickly gather enough capital to enable us to return to Bosnia and Herzegovina to start a family business or to buy our own family home. Perhaps we would stay here permanently, you never know."

Respondent $\mathbf{O}$ (Montenegro, 52): "Since both my husband and I are over 50 years of age and that we have been in Norway for almost 20 years, our plan is to get our pensions here and then spend most of the year enjoying ourselves at home in Montenegro."

\section{Conclusion}

By consulting the literature that dealt with the migration of hospitality workers, with a focus on Scandinavian countries, and in order to find answers to the research questions for workers from Western Balkans, it has been concluded that Norway is becoming an increasingly attractive destination for employment:

- Among the employees in hospitality facilities, men aged between 30 and 40 with completed high school in their countries of origin are most numerous. There were few women among the respondents for the needs of the research, as well as few workers who are not from the catering profession.

- The reasons for the selection are simple. Norway was selected in order to find good working conditions accompanied by a solid income, which would provide their families with better living conditions.

- The experiences at work are positive and the environment is often described to be stressfree and respectful, which has been one of the important reasons for choosing this environment in recent years.

- This builds on satisfaction with work and living conditions as a crucial factor in retention.

- The research showed that the future plans of employees are related to the destination itself, as long as the mutual benefit and satisfaction are achieved, which primarily refers to better working and living conditions of migrant workers in this Scandinavian country.

\section{Future research}

The future research could be conducted on a larger number of employees in tourism and hospitality industries (interviewing) and in that way get more detailed information on working conditions and satisfaction in relation to those in their countries of origin.

\section{Acknowledgment}

The authors acknowledge financial support of the Ministry of Education, Science and Technological Development of the Republic of Serbia (Grant No. 451-03-68/2020-14/200125) 


\section{Literature}

Allen, H., Mac Con Iomaire, M. 2016. "Against all odds": Head chefs profiled. Journal of Culinary Science and Technology 14(2), 107-135.

Allen, H., Mac Con Iomaire, M. 2017. Secrets of a Head Chef: Exploring Factors Influencing Success in Irish Kitchens. Journal of Culinary Science and Technology 15(3), 187-222.

Alverén, E., Andersson, T., Eriksson , K., Sandoff, M., Wikhamn, W. 2012. Seasonal employees' intention to return and do more than expected. The Service Industries Journal 32(12), 1957-1972.

Bosworth, G., Farrell, H. 2011. Tourism entrepreneurs in Northumberland. Annals of Tourism Research 38(4), 1474-1494.

Brotherton, B. (2015) Researching Hospitality and Tourism. SAGE.

Bubalo-Živković, M., Đerčan, B., Stojisavljević, R. (2017). Geography of Serbia. University in Novi Sad, Faculty of Sciences, Department of Geography, Tourism and Hotel Management.

Bufquin, D., DiPietro, R., Orlowski, M., Partlow, C. 2016. The influence of restaurant co-workers' perceived warmth and competence on employees' turnover intentions: The mediating role of job attitudes. International Journal of Hospitality Management 6o, 13-22.

Bufquin, D., DiPietro, R., Orlowski, M., Partlow, C. 2017. The influence of restaurant co-workers' perceived warmth and competence on employees' turnover intentions: the mediating role of job attitudes. International Journal of Hospitality Management 6o, 13-2.

Carson, D.A., Carson, D.B. 2017. International lifestyle immigrants and their contributions to rural tourism innovation: Experiences from Sweden's far north. Journal of Rural Studies 64, 230-240.

Carson, D.A., Carson, D.B., Eimermann, M. 2017. International winter tourism entrepreneurs in northern Sweden: understanding migration, lifestyle, and business motivations. Scandinavian Journal of Hospitality and Tourism 18/2, 183 - 198.

Chan, J., Wang, W. 2015. Foreign labours in Arctic destinations: seasonal workers' motivations and job skills. Current Issues in Tourism 18(4), 350-360.

Choi, J.-G., Woods, R., Murrmann, S. 2ooo. International labour markets and the migration of labour forces as an alternative solution for labour shortages in the hospitality industry. International Journal of Contemporary Hospitality Management 12(1), 61-67.

Commissariat for Refugees and Migration, Migration Profile for 2016. The government of Republic of Serbia (http://www.kirs.gov.rs/docs/migracije/migracioni\%2oprofil\%202015. pdf) (in Serbian)

Devine, F., Baum, T., Hearns, N., Devine, A. 2007. Cultural diversity in hospitality work: the Northern Ireland experience. The International Journal of Human Resource Management 18(2), 333-349.

Fine, A. 1990. Organizational Time: Temporal Demands and the Experience of Work in Restaurant Kitchens. Social Forces 69(1), 95-114.

Fraser, S., Lyon, P. 2017. Chef Perceptions of Modernist Equipment and Techniques in the Kitchen. Journal of culinary science and technology 16(1), 88-105.

Hansen, K.V., Jensen, O., Gustaffson, I.B. 2005. The meal experiences of a la carte restaurant customers. Scandinavian Journal of Hospitality and Tourism 5(2), 135-151.

Heimtun, B. 2012. Life in the bubble: The leisure experiences of female Swedish seasonal hospitality workers in Nordkapp, Norway. Hospitality and Society 2(2), 159-178. 
Iversen, I., Jacobsen, J.S. 2015. Migrant Tourism Entrepreneurs in Rural Norway. Scandinavian Journal of Hospitality and Tourism 16(4), 1-16.

Janta, H., Ladkin, A., Brown, L., Lugosi, P. (2011. Employment experiences of Polish migrant workers in the UK hospitality sector. Tourism Management, 32(5), 1006-1019.

Jupe, M. 2012. Migrant workers: Challenges and opportunities in addressing tourism labour shortages. Tourism Management 33(3), 662-671.

Kalenjuk, B., Đerčan, B., Tešanović, D., Banjac, M. 2020. Norwegian hospitality as a focus of interests of labour migrantsfrom Bosnia and Herzegovina and Republic of Serbia. X scientific conference with international participation, Jahorina business forum 2020, Real and financial sector in the light of new technologies, new world trends andnew challengesjahorina, 23rd-25th March 2020, Faculty of Economics Pale , University of East Sarajevo, $407-412$.

King, H.J., Gatling, A., Kim, J. 2015. The Impact of Supervisory Support on Organizational Commitment, Career Satisfaction, and Turnover Intention for Hospitality Frontline Employees. Journal of Human Resources in Hospitality and Tourism 14(1), 68-89.

Kostadinov Koroutchev, R., Iashvili, I. 2015. Skilled migration in Georgia and its contribution to the country's development. Zbornik radova Departmana za geografiju, turizam $i$ hotelijerstvo 44/2, 128- 145 .

Lundberg, C., Gudmundso, A., Andersson, T. 2009. Herzberg's Two-Factor Theory of work motivation tested empirically on seasonal workers in hospitality and tourism. Tourism Management 30(6), 890-899.

Lundmark, L. 2006. Mobility, migration and seasonal tourism employment: Evidence from Swedish mountain municipalities. Scandinavian Journal of Hospitality and Tourism, 6, 197-213.

Mac Con Iomaire, M. 2016. Food on the Edge: The future of food is a sustainable future, Research in Hospitality Management 6(1), 107-111.

Magnusson Sporre, C., Johnson, I. M., Ekström, M. P. 2015. The complexity of making a conscious meal: A concept for development and education. Journal of Culinary Science and Technology 13(3), 263-285.

McCabe, R., Nowak, M., Mullen, S. 2005. Nursing Careers: What Motivated Nurses to Choose their Profession?. Australian Bulletin of Labour 31(4), 384-406.

Möller, C., Ericsson, B., Overvåg, L. 2014. Seasonal Workers in Swedish and Norwegian Ski Resorts - Potential In-migrants? Scandinavian Journal of Hospitality and Tourism 14(4), 385-402.

Neobilten, Average earnings per employee in the Republic of Serbia (2017) (http://www.neobilten.com/prosecne-zarade-po-zaposlenom-u-republici-srbiji/) (in Serbian)

Neuman, N. 2017. An imagined culinary community: stories of morality and masculinity in "Sweden - the new culinary nation". Scandinavian Journal of Hospitality and Tourism 18/2, 149-162.

Neuman, N., Gottzén, L., Fjellström, C. 2016. Masculinity and the sociality of cooking in men's everyday lives. The Sociological Review 65(4), 816-831.

Paniagua, A. 2002. Urban-rural migration, tourism entrepreneurs and rural restructuring in Spain. Tourism Geographies 4(4), 349-371.

Rye, J. F., Andrzejewska, J. 2010. The structural disempowerment of Eastern European migrant farm workers in Norwegian agriculture. Journal of Rural Studies 26, 41-51.

Skalpe, O. 2003. Hotels and restaurants - Are the risks rewarded? Evidence from Norway. Tourism Management 24(6), 623-634. 
StatBank source table o7284 (https://www.ssb.no/en/innvregsys/)

Susskind, A., Kacmar, M., Borchgrevink, C. 2007. How organizational standards and coworker support improve restaurant service. Cornell Hotel and Restaurant Administration Quarterly 48(4), 370-379.

The International Labour Organization (ILO) (http://www.ilo.org/global/topics/labour-migration/lang--en/index.htm)

Thulemark, M., Ludmark, M., Heldt-Cassel, S. 2014. Tourism Employment and Creative In-migrants. Scandinavian Journal of Hospitality and Tourism 14(4), 403-421.

Tuulentie, S., Heimtun, B. 2014. New Rural Residents or Working Tourists? Place Attachment of Mobile Tourism Workers in Finnish Lapland and Northern Norway. Scandinavian Journal of Hospitality and Tourism 14(4), 367-384.

Underthun, A., Jordhus-Lier, D.C. 2017. Liminality at work in Norwegian hotels. Tourism Geographies $20(1), 11-28$.

Wellton, L., Jonsson, I.M., Svingstedt, A. 2017. "Just trained to be a chef, not a leader": A study of head chef practices. International Journal of Hospitality and Tourism Administration, Published online: 15 Nov 2017, In Press.

Wildes, V., Parks, S. C. 2005. Internal service quality: Marketing models can help to reduce employee turnover. International Journal of Hospitality and Tourism Administration 6(2), $1-27$.

Wildes, V., Parks, S.C. 2005. Internal service quality: Marketing models can help to reduce employee turnover. International Journal of Hospitality and Tourism Administration 6(2), $1-27$.

Wildes, V.J. 2008. Should I stay or should I go? Motivation to work in foodservice. Journal of Foodservice Business Research 11(3), 286-294.

Zampoukos, K., Ioannides, D. 2011. The tourism labour conundrum: agenda for new research in the geography of hospitality workers. Hospitality and Society 1(1), 25-45.

Zopiatis, A., Theodosiou, P., Constanti, P. 2014. Quality and satisfaction with culinary education: Evidence from Cyprus. Journal of Hospitality and Tourism Education 26(2), 87-98. 